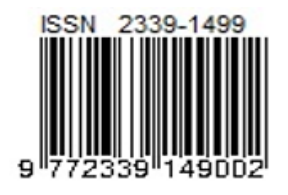

Paper ini telah direview dan dipublikasikan di Jurnal Rekayasa Sistem Industri Volume 6 No.2 Oktober 2017

\title{
Evaluation Of Service Quality For Undergraduate Programs At Andalas University
}

\author{
Nilda Tri Putri ${ }^{1 *}$, Alexie Herryandhi Broto Adi $^{2}$, Ryan Kamal Fikri ${ }^{3}$ \\ 1,2,3 Faculty of Engineering, Department of Industrial Engineering, Andalas University \\ Kampus Unand Limau Manis, Padang West Sumatra, 25163 \\ Email: nildatriputri@gmail.com*, riankamalfikri@gmail.com
}

\begin{abstract}
Total Quality Management is a philosophy and key to bring success in the industry for this era. Total Quality Management plays an important role in the management system and culture to create or produce a good products and service. Andalas University is one object of the application of Total Quality Management in the education sector. Research carried out aims to describe the service quality for undergraduate programs at the Andalas University. Based on the measurement of the service quality, obtained the information related to the level of student satisfaction each Departments and priority improvements to service variable. The study used a questionnaire with two instrument ratings. The instruments rating are an assessment of the level of service and service priority. The calculation for service quality used CSI (Customer Satisfaction Index) method. The recommendations for improve service quality used IPA (Importance Performance Analysis) Method. Based on research conducted, service quality Undergraduate Program at Andalas University can be categorized as low. It was based on the value of CSI located on the 4th lowest category, which is one of courses in Very Poor category, 9 courses in Poor category, 3 courses in the Cause for Concern category, and 1 course on Borderline category. While the dimensions of which are in the service of a general improvement priorities is the Tangible and Reliability dimension.
\end{abstract}

Keywords: Customer Satisfaction Index, Important Performance Analysis, Service Quality

\section{Introduction}

University is the best medium in apply the concept of Total Quality Management. This is evidenced by the function of universities that have similarities to the manufacturing industry. Total Quality Management plays an important role in the management system and culture to create or produce a good products and service. The products that 
produce by university is students and knowledge, and service quality was produced by academic staff and employees. The needed of Total Quality Management in higher education also occurred in Indonesia. Not all University has applied the concept of Total Quality Management properly. The success of universities in Indonesia in the application of Total Quality Management can be assessed from the accreditation which is owned by the University. The relationship between the success of the application of Total Quality Management to this accreditation can be seen from the similarities between the assessment standards established by the National Accreditation Board of Higher Education in Indonesia with the output of Total Quality Management is a product (university graduates and knowledge) and service quality.

Andalas University is one of the oldest universities in Indonesia. In general, Andalas University, has applied the concept of Total Quality Management properly. This is indicated by the University of Andalas valuable accreditation A. However, it can not be assumed that the application of Total Quality Management has been applied for each program of study at the University of Andalas. One of the problems that happened was that there was still an accredited study program C.

This proves that some courses have to do a self-evaluation in order to improve the internal quality of the courses themselves with the guidelines provided by National Accreditation Board of Higher Education in Indonesia. One of the self-evaluation needs to be done is an internal evaluation program of study in terms of service quality. Service Quality becomes the main focus in the internal evaluation of study programs as closely associated with the process and outcomes of courses. Therefore, it is necessary to conduct further research related to service quality for each program of study at the Andalas University.

\section{Literature Review}

In the study conducted by Todorut (2013), Total Quality Management means the whole set of elements that exist within an organization ranging from the process, training, systems, and method and entirely belonging to the quality of a product or service. The main objective of Total Quality Management is to create comfortable conditions for all existing resources capable of being used in a creative and efficient in its management. Additionally Hellsten, $\mathrm{H}$ and Klefsjo, B. (2000) in Todorut (2013) Total Quality Management can also be defined as a management strategy focused on 
three units, namely core values, tools, and technique.

There are several points to consider in Total Quality Management, namely (Todorut, 2013): Change, Customer Orientation, Communication, Continuous Improvement, Corrective Measure, Cost of Poor Quality, and organisational structure of the network type in the Process or case management, Imagination, Creativity, Information Technology, Organizational Culture, Team, Orientation towards the Future. Application of Total Quality Management in Higher Education has the potential to (Hebert et al., (1995); Vazzana et al., (1997) in Cruickshank, 2010): Administration of University Function, Curricula dan Core Learning Processes, Teaching Methods, Research Activities, non-Academic functions [Hebert et al. 1995; Vazzana et al. 1997].

\section{Methodology}

\subsection{Dimensions of Service Quality Measurement}

The instrument used to measure the service quality for undergraduate program at Andalas University is a questionnaire. Questionnaires are designed using variables of service quality that is formed from multiple dimensions. Questionnaire survey used in this research can be seen at Appendix A. Dimensions of service quality were based on research
Owlia and Aspinwall in Sudha (2013) shown in Table 1.

Table 1: Quality Dimensions in Higher Education (Sudha, 2013)

\begin{tabular}{|c|c|}
\hline Dimension & Characteristics \\
\hline \multirow{4}{*}{ Tangible } & Sufficients equipments / facilities \\
\hline & Ease of acces \\
\hline & Visually appealing environment \\
\hline & $\begin{array}{l}\text { Support services (accomdation, } \\
\text { sports, etc) }\end{array}$ \\
\hline \multirow{3}{*}{ Competence } & Sufficients staff (academic) \\
\hline & $\begin{array}{l}\text { Theoretical and practical } \\
\text { knowledge, qualifications }\end{array}$ \\
\hline & $\begin{array}{l}\text { Teaching Experience, } \\
\text { communication }\end{array}$ \\
\hline \multirow{4}{*}{ Attitude } & Understanding students needs \\
\hline & Willingness to help \\
\hline & $\begin{array}{l}\text { Availability for guidence and } \\
\text { device }\end{array}$ \\
\hline & Giving personal attention \\
\hline \multirow{4}{*}{ Content } & $\begin{array}{l}\text { Relevance of curriculum to the } \\
\text { future jobs of the student }\end{array}$ \\
\hline & $\begin{array}{l}\text { Communication skill and team } \\
\text { work }\end{array}$ \\
\hline & $\begin{array}{l}\text { Flexibility of knowledge, being } \\
\text { cross-diciplinary }\end{array}$ \\
\hline & $\begin{array}{l}\text { Containing primary } \\
\text { knowledge/skills }\end{array}$ \\
\hline \multirow{4}{*}{ Delivery } & Effective presentation \\
\hline & Sequencing timeliness \\
\hline & $\begin{array}{l}\text { Consistency, fairness of } \\
\text { examinations }\end{array}$ \\
\hline & Feedback from students \\
\hline \multirow{3}{*}{ Reliability } & Trustworthiness \\
\hline & Giving valid award \\
\hline & $\begin{array}{l}\text { Handling complaints, solving } \\
\text { problems }\end{array}$ \\
\hline
\end{tabular}

\subsection{Custumer Satisfaction Index (CSI) Method}

Customer Satisfaction Index (CSI) is useful to know the level of customer satisfaction with services provided by the service provider. 
Steps to calculate the value of CSI are as follows (Syukri, 2014):

1. Determine the Value of Mean Importance Score (MIS) for each variable question

2. Identify Weight Factor (WF) for each variable question. This weight is obtained by dividing the MIS per variable with a total value of MIS

3. Determining Mean Satisfaction Score (MSS) for each variable question

4. Calculate Weight Score (WS $\left.\mathrm{S}_{\mathrm{k}}\right)$ for each variable question. This value is obtained by multiplying the value of MSS with WF.

5. Calculate the value of Customer Satisfaction Index (CSI) using the formula:

$$
C S I=\frac{\sum_{k=1}^{p} W S_{k}}{H S} \times 100 \%
$$

Table 2: Interpretation of CSI (Customer Satisfaction Index) (Syukri, 2014)

\begin{tabular}{|c|c|}
\hline Index Range & Interpretation \\
\hline $\mathrm{X}>87 \%$ & Excellent \\
\hline $84 \%<\mathrm{X} \leq 87 \%$ & Very Good \\
\hline $80 \%<\mathrm{X} \leq 84 \%$ & Good \\
\hline $77 \%<\mathrm{X} \leq 80 \%$ & Borderline \\
\hline $71 \%<\mathrm{X} \leq 77 \%$ & Cause for Concern \\
\hline $64 \%<\mathrm{X} \leq 71 \%$ & Poor \\
\hline $\mathrm{X} \leq 64 \%$ & Very Poor \\
\hline $\mathrm{X}=$ Costumer Satisfaction Index
\end{tabular}

Highest Scale (HS) is the maximum scale used. Interpretation 132 of the value of the CSI (Customer Satisfaction Index can be seen in Table 2:

\subsection{Important Performance Analysis (IPA) Method}

Importance Performance Analysis (IPA) method is used to see the improvement priority. In general, Importance Performance Analysis (IPA) dividing improvement priorities into four quadrants as shown in Figure 1:

\begin{tabular}{l|c} 
A. Concentrate Here & Extremely Important \\
Fair & B Keep Up The Good Work \\
\hline Performance & Performance \\
C. Low priority & D. Possible Overkill
\end{tabular}

Figure 1:. Importance Performance Analysis (IPA) Matrix (Martilla \& James, 1977 in Kitcharoen, 2004)

\section{Results and Discussion}

The Calculation of CSI (Customer Satisfaction Index) is used to determine the level of customer satisfaction with the services provided. The value of the CSI (Customer Satisfaction Index) is shown as a percentage. Table 3 shows a recapitulation of the value of CSI (Customer Satisfaction Index) for the entire Department:

Table 3: Recapitulation of Costumer Satisfaction Index for 
Undergraduate Program at Andalas University

\begin{tabular}{|c|c|c|c|}
\hline Department & $\begin{array}{l}\text { Accredi- } \\
\text { tation }\end{array}$ & CSI & Category \\
\hline $\begin{array}{l}\text { Indonesian } \\
\text { Literature }\end{array}$ & B & $79.48 \%$ & Borderline \\
\hline Biology & A & $73.55 \%$ & \multirow{3}{*}{$\begin{array}{c}\text { Cause For } \\
\text { Concern }\end{array}$} \\
\hline Physics & B & $72.98 \%$ & \\
\hline $\begin{array}{l}\text { Japanese } \\
\text { Literature }\end{array}$ & $\mathrm{C}$ & $71.00 \%$ & \\
\hline $\begin{array}{l}\text { International } \\
\text { Relations } \\
\text { Science }\end{array}$ & B & $70.66 \%$ & \multirow{9}{*}{ Poor } \\
\hline $\begin{array}{l}\text { Mechanical } \\
\text { Engineering }\end{array}$ & A & $70.07 \%$ & \\
\hline $\begin{array}{l}\text { Computer } \\
\text { Science }\end{array}$ & $\mathrm{C}$ & $69.14 \%$ & \\
\hline $\begin{array}{l}\text { Nursing } \\
\text { Program }\end{array}$ & $\mathrm{B}$ & $68.51 \%$ & \\
\hline Pharmacy & A & $67.83 \%$ & \\
\hline $\begin{array}{l}\text { Enviromental } \\
\text { Engineering }\end{array}$ & B & $67.67 \%$ & \\
\hline Management & A & $67.28 \%$ & \\
\hline $\begin{array}{l}\text { Industrial } \\
\text { Engineering }\end{array}$ & A & $66.18 \%$ & \\
\hline Agribusiness & $\mathrm{B}$ & $64.58 \%$ & \\
\hline $\begin{array}{l}\text { Dentist } \\
\text { Program }\end{array}$ & $\mathrm{C}$ & $61.14 \%$ & Very Poor \\
\hline
\end{tabular}

According to the table, there was information that on the 14 department, interpretation of the results obtained 4 CSI (Customer Satisfaction Index). The interpretation is Borderline, Cause for Concern, Poor and Very Poor. This assessment is at its lowest 4 of 7 interpretations of interpretations on CSI (Customer Satisfaction Index). This interpretation shows that the level of customer satisfaction of 14 depatments is still relatively low in general.

Interpretation with the highest ratings is the Literary Studies Program Indonesia with
Borderline category with a CSI score of $79.48 \%$. This interpretation shows that the level of student satisfaction with service qualitys provided by Program classified as normal. This interpretation occurs because the performance of academic staff of Indonesian Literature Department in providing services of various variables ratings considered quite good by the students. Pretty good service is coupled with expectations of students that did away with the service qualitys provided by the Program.

The next interpretation is the interpretation of CSI by category Cause for Concern. Courses that are included in this category is the Department Biology, Physics, and Japanese Literature. This category indicates the service qualitys provided by the Program are advised to conduct the evaluation. This happens because the gap between students 'perceptions of academic staff's performance in terms of service to the students' expectations of service delivery. Gaps are not too significant, so that the performance evaluation program of study in terms of service do not need to be done immediately.

Interpretation with the highest Studies Program is the interpretation of the value of CSI with the Poor category. There are nine courses of study that fit into this category, namely the International 
Relations Science, Mechanical Engineering, Computer Science, Nursing, Pharmacy, Environmental Engineering, Management, Industrial Engineering and Agribusiness. This category indicates that the level of student satisfaction on the performance of service Department is low. The main issues contained in this category are the presence of some of the Department with accreditation by 4 courses. This shows that the accreditation owned courses are not relevant to the current level of student satisfaction. The low value of the CSI is the case because of the large gaps between performance studies program in providing services with the expectation of service desired by the students.

The lowest category is very poor. Courses that fit into this category is a Dentist Education. This category indicates that the level of student satisfaction dental education as very low. Students assess that performance in the Department provides academic services is very far from the expectations of students to these services. Department should conduct an evaluation of the service quality as soon as possible. The level of student satisfaction is also relevant to the accreditation of educational courses dentists still worth C. Moreover, this gap occurs because this program is still relatively new.
Important Performance Analysis for each service dimension for Undergraduate Program at Andalas University can be seen generally at Figure 2.

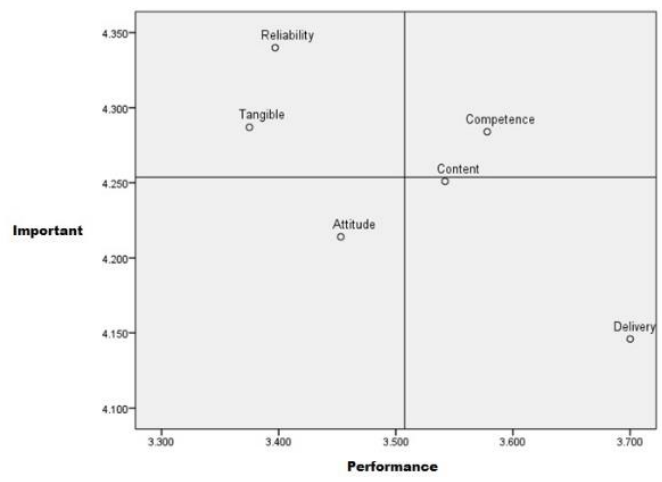

Figure 2: Important Performance Analysis for Undergraduate Program at Andalas University

Based on Figure 2, there was information that the main issues for each program of S-1 at Andalas University are a dimension Tangible and Reliability. This shows still need to be evaluated related facilities and infrastructure of academic and non-academic. In addition to the means-and the academic infrastructure, the evaluation also needs to be made to services that are of Student Affairs. While the dimensions of Competence, performance of academic services is considered very good and should be maintained. This is evidenced by the dimensions of Competence which are in quadrant II, whereas the low priority occurs on the dimensions of Attitude. This shows that the 
students assess these dimensions needs to be improved, but not a top priority. High expectations occur on the dimensions of Content and Delivery. This indicates that the service performance is very high but not so important by students.

At Tangible dimension, improvement needs to be done completeness of laboratory equipment, completeness and recency collection of the library department, the ease of access to ejournal of research, and the cleanliness of the toilet majors. This needs to be considered by the Andalas University, because according to Internal Quality Policy Andalas University Year 2013-2016 Chapter III Article 14 Paragraph 3 describes the obligation of Andalas University in developing research infrastructure and facilities that are easily accessible all the academicians and the user community. Academicians in the Quality Policy Internal Andalas University Year 2013-2016 Chapter I Article 1 Paragraph 15 is Lecturers and Students Unand. This shows that the research facilities must be easily accessible to students and always developed by the Andalas University. In addition, based on Internal Quality Standards Andalas University Year 2013-2017 9 Part 28 Standards No. 82 stated that the laboratory should have equipment with the type and amount balanced with practical activities and student research.
At dimensions of Reliability, repairs need to be done are in softksill training, socialization race or national and international events, scholarships institutional and noninstitutional, seminars and workshops related to the world of work, research information, the provision of facilities in extracurricular activities and social activities. Improvements on this variable refer to the Standards of Quality Standards Internal Affairs Component 614 Number 47 which explains the importance of university services to students, especially to components such as interest and talent, scholarship, health. While the Standard Components 6514 No. 50, there's a need for the University to improve student achievement in both the academic and non-academic. Surely this is the basis of the University in developing any activities, facilities and infrastructure, as well as information relating to Student Affairs.

\section{References:}

Cruickshank, Mary. (2010). Total Quality Management in the Higher Education Sector: A Literature Review from An International and Australian Perspective. TQM and Business Excellence. Volume 14, No. 10, Hal 1159-1167

Hebert, F.J., Dellana, S.A. \& Bass, K. (1995) Total quality management in the business school: the faculty 
viewpoint, Advanced Management Journal, 60, pp. 20-31.

Hellsten H. \& Klefsjo, B. (2000). "TQM as Management in Higher Education". Asian Journal of Business Management. No.2, pp 916.

Kitcharoen, Krisana. (2004). The Importance Performance Analysis of Service Quality In Administrative Departments Of Private Universities In Thailand. ABAC Journal. Volume 24, Number 3. Hal 20-46

Martilla, J. and James J. (1977), 'Importance- Performance Analysis', Journal of Marketing, 14 (January): pp. 77-79

Sudha, T. (2013). Total Quality Management In Higher Education Institutions. International Journal of Social Science \& Interdisiplinery Research Volume 2, No. 6, ISSN 22773630

Syukri, Siti Husna Ainu. (2014). Penerapan Customer Satisfaction Index (CSI) dan Analisis Gap Pada Kualitas Pelayanan Trans Jogja. Jurnal Ilmiah Teknik Industri. Volume 13, Nomor 2. ISSN 14126869

Todorut, Amalia Venera. (2013). The Need of Total Quality Management in Higher Education. Procedia - Social and Behavioral
Sciences 83 (2013). No. 1105 1110.

Vazzana, G., Bachman, D. \& Elfrink, J. (1997) Does higher education practice what it teaches?: A study of total quality management processes in academia answers this question, Quality Progress, 30, pp. 67-74. 


\section{APPENDIX A}

\section{Survey Instruction}

\section{Part 1 : Respondent Identity}

Before answer the questionnaire, please fill in your data on this field:

- Name

- Student Number :

- Gender : Male / Female

- Faculty

- Study Program :

- BSS Status : Ever/Never

\section{Part 2 :Survey Instruction}

Please checklist $(\sqrt{ })$ in the column provided on the right side of the question in accordance with your perception of quality. The assessment:

\begin{tabular}{|l|c|l|l|c|}
\hline \multicolumn{2}{|c|}{ Assessment of Quality } & \multicolumn{2}{c|}{ Level of Service Importance } \\
\hline \multicolumn{1}{|c|}{ Criteria } & Code & & \multicolumn{1}{c|}{ Criteria } & Code \\
\hline Not Very Good & VNG & & Not Very Important & NVI \\
\hline Not Good & NG & & Not Important & NI \\
\hline Moderate & M & & Moderate & M \\
\hline Good & G & & Important & I \\
\hline Very Good & VG & & Very Important & VI \\
\hline
\end{tabular}

Here is an example of the filling survey:

\begin{tabular}{|c|c|c|c|c|c|c|c|c|c|c|}
\hline \multirow{2}{*}{ Questionnaire } & \multicolumn{5}{|c|}{ Assessment of Quality } & \multicolumn{5}{|c|}{ Level of Service Importance } \\
\hline & VNG & NG & $\mathbf{M}$ & $\mathbf{G}$ & VG & NVI & NI & $\mathbf{M}$ & I & VI \\
\hline Question 1 & & & & $\sqrt{ }$ & & & $\sqrt{ }$ & & & \\
\hline Question 2 & & & $\sqrt{ }$ & & & $\sqrt{ }$ & & & & \\
\hline Question 3 & & & $\sqrt{ }$ & & & & & $\sqrt{ }$ & & \\
\hline
\end{tabular}




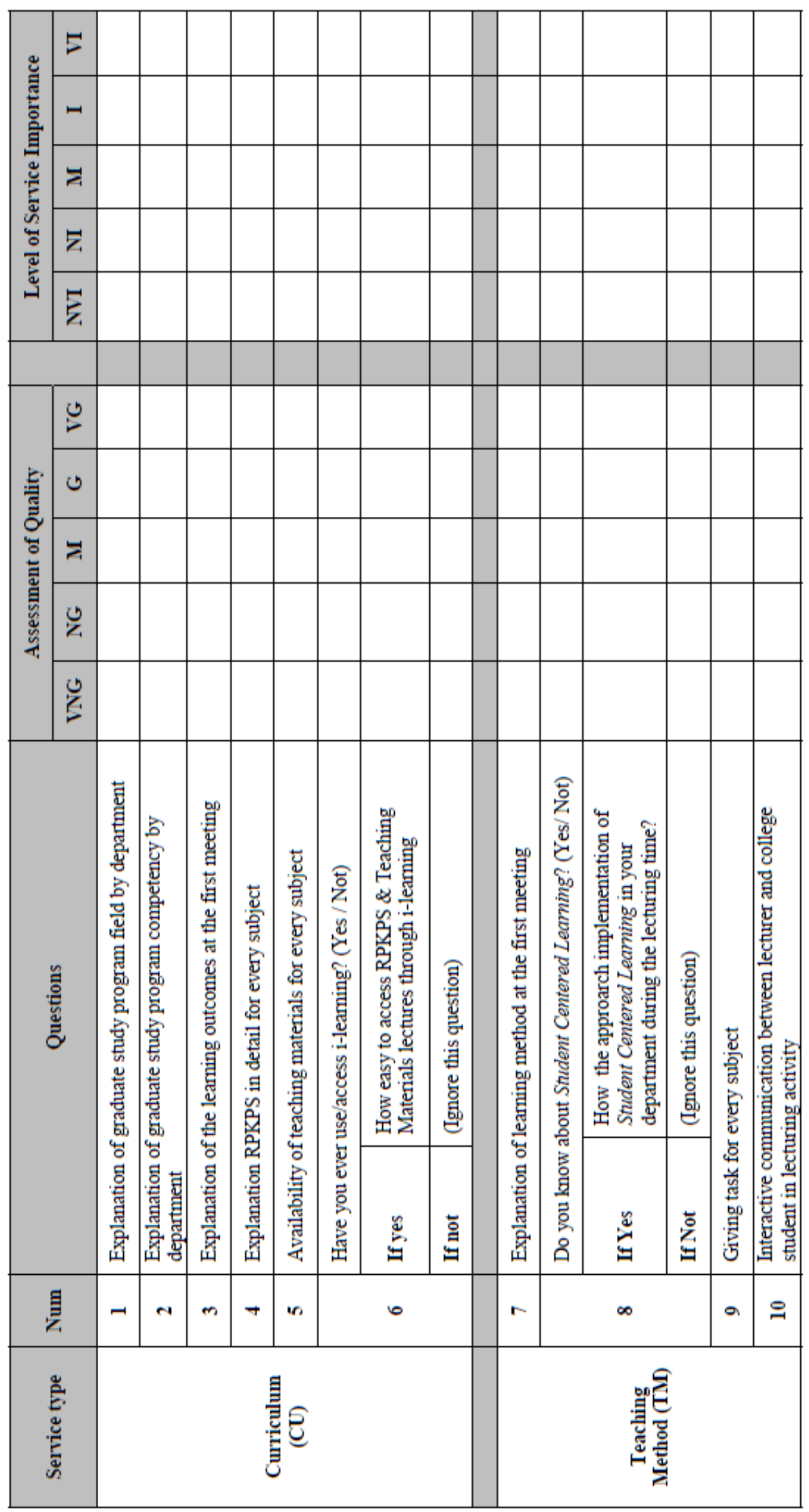




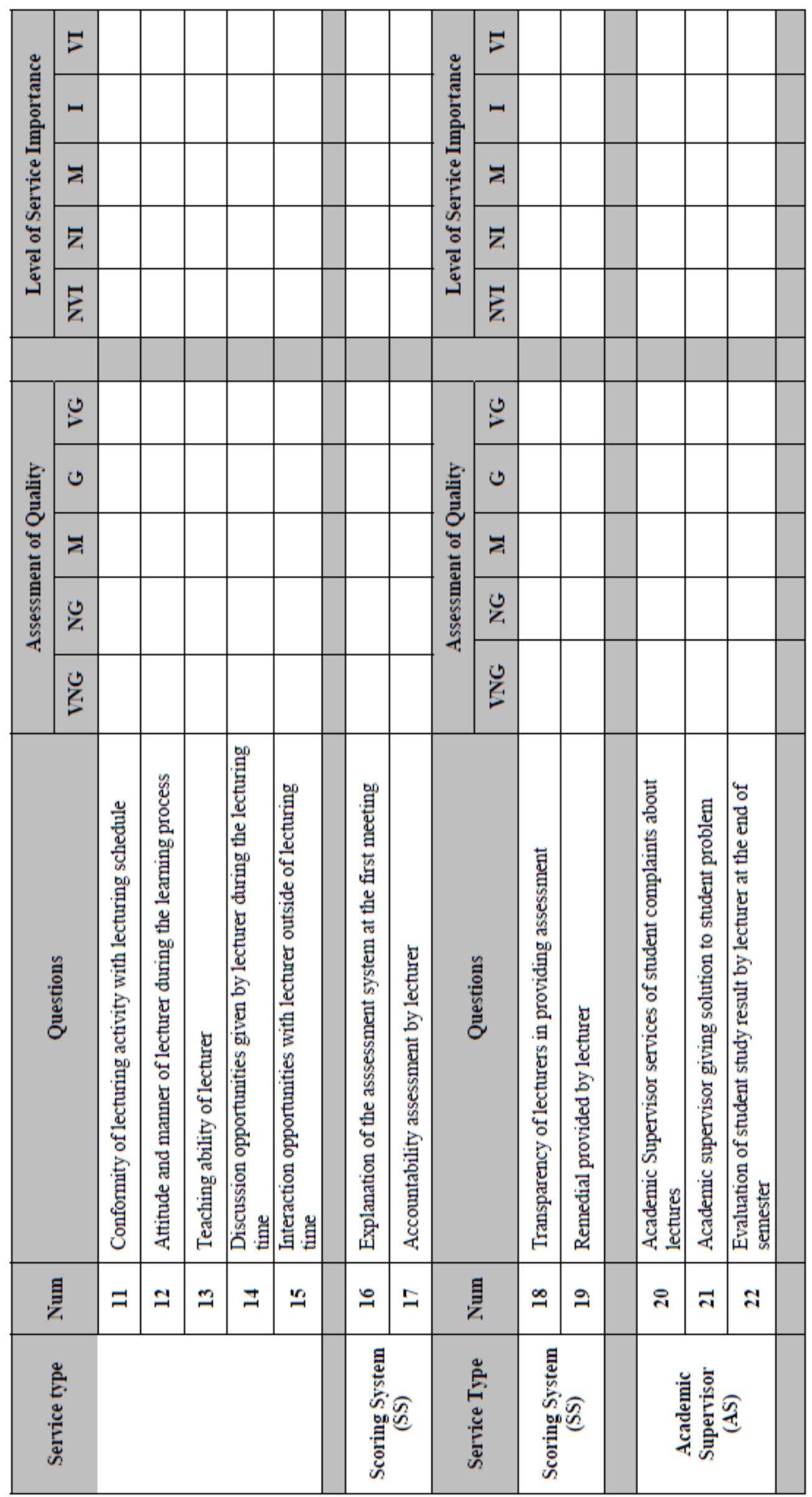




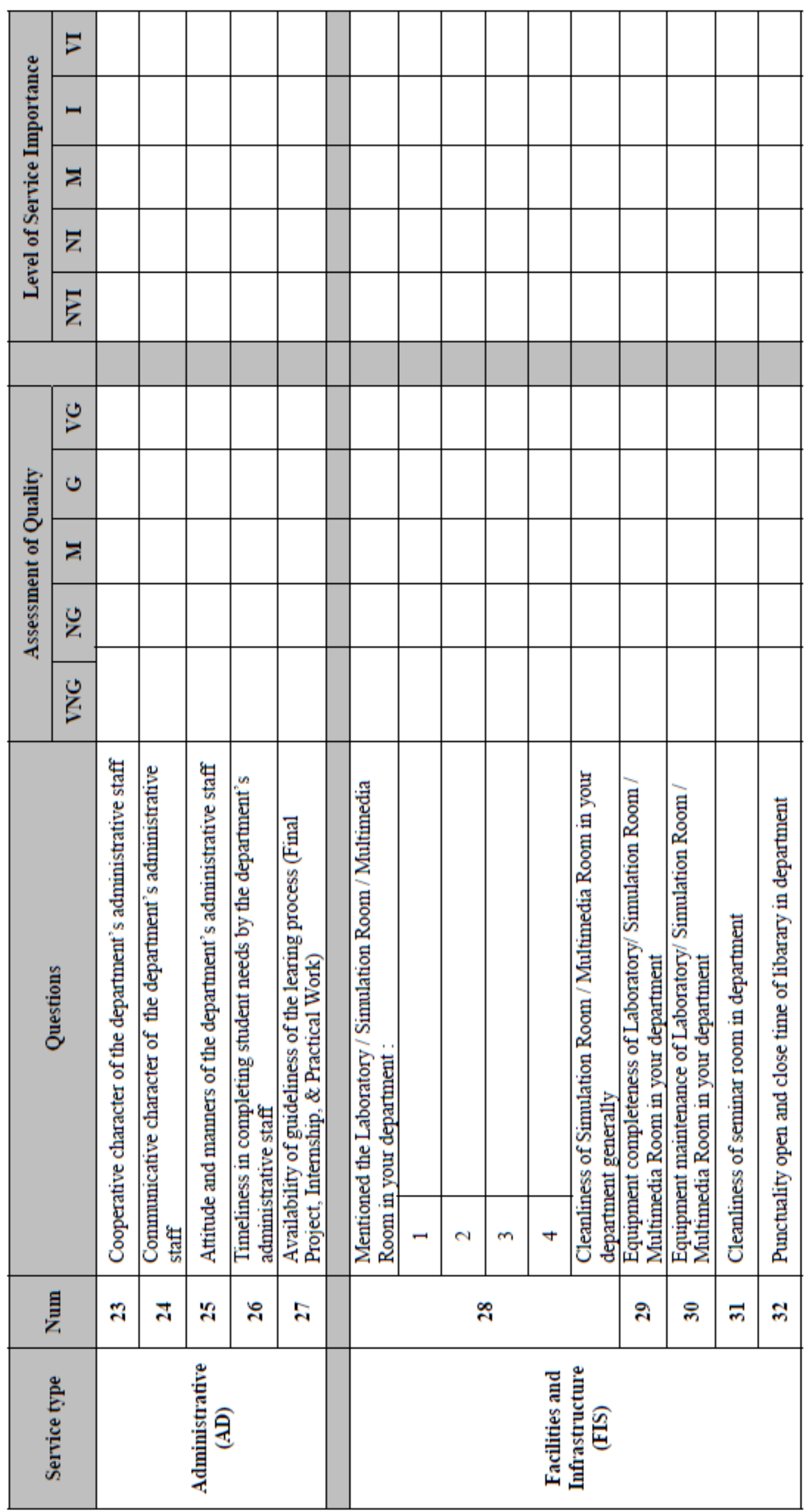




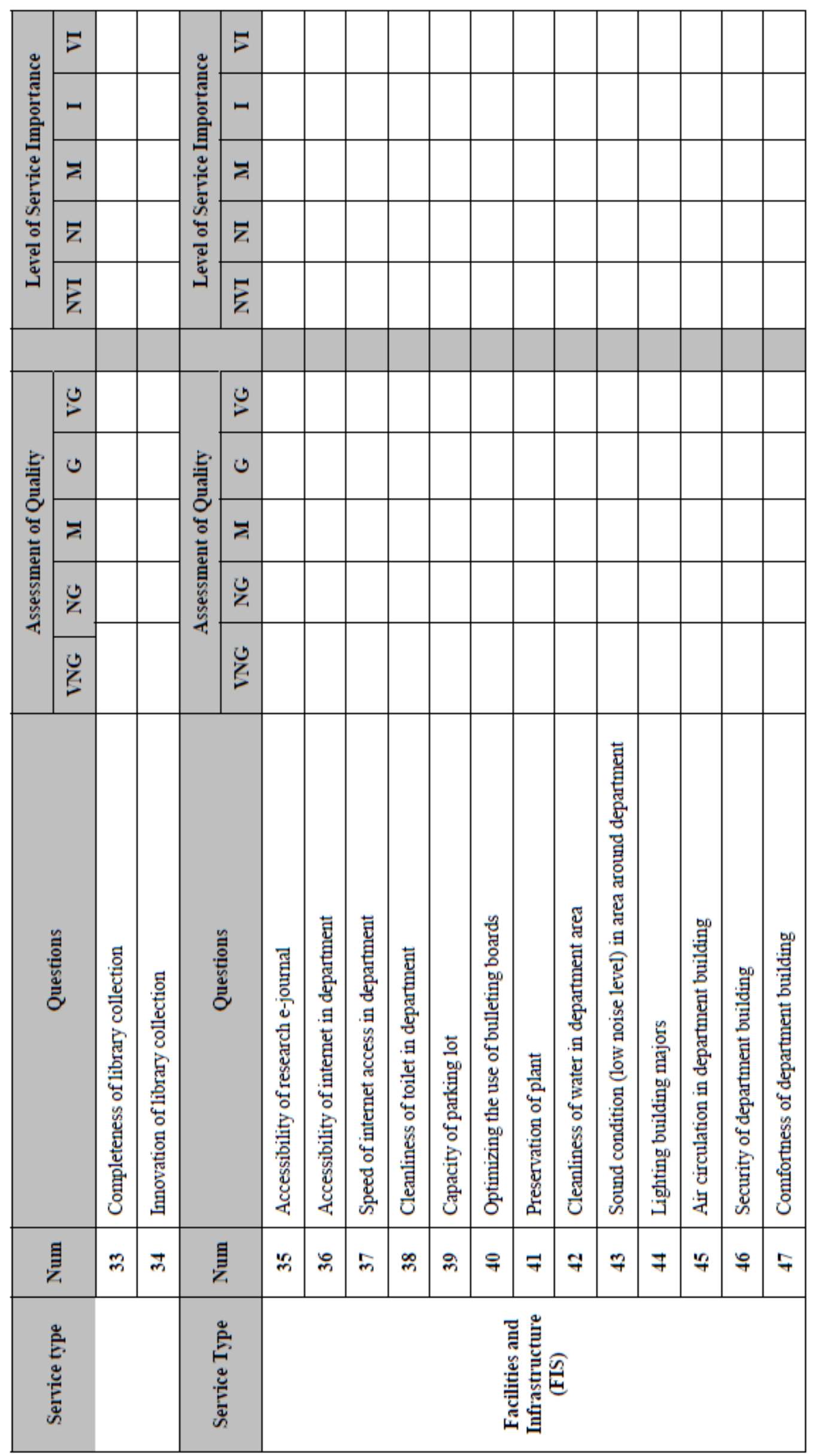




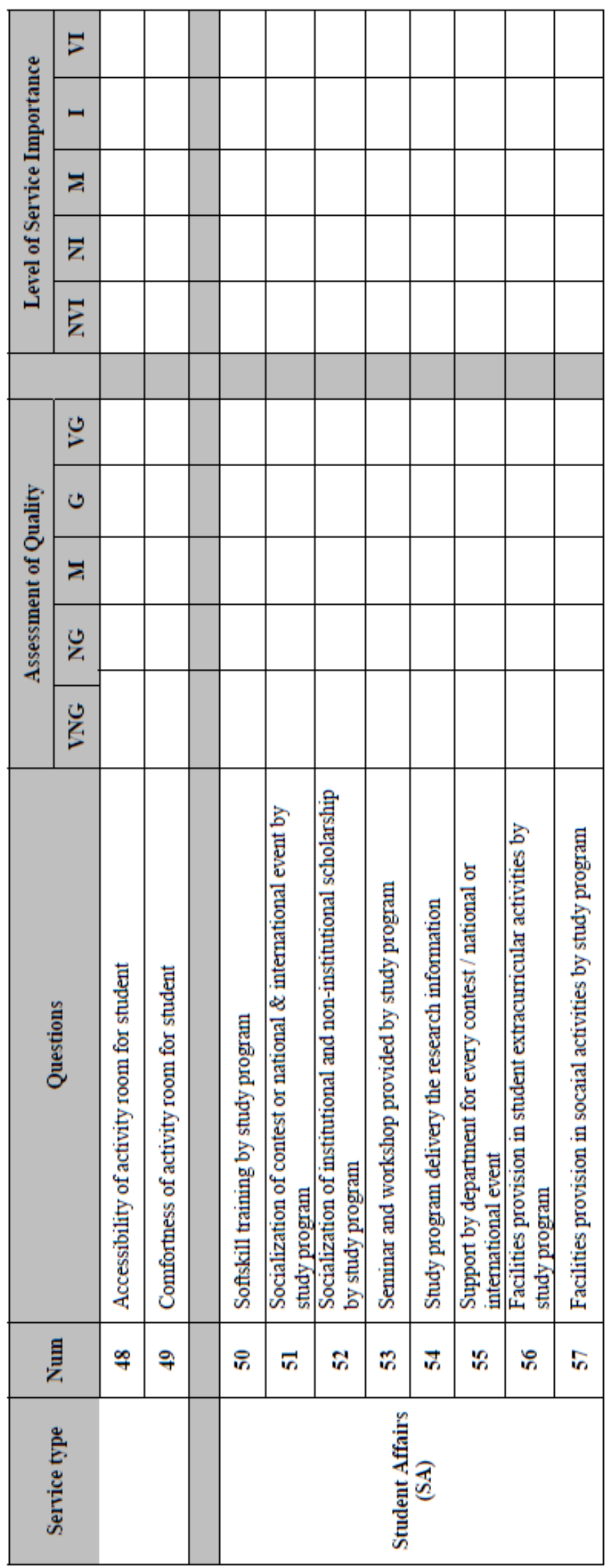

